Purdue University

Purdue e-Pubs

Charleston Library Conference

\title{
Subject Librarian Initiative at the University of Central Florida Libraries: Collaboration Amongst Research and Information Services, Acquisitions and Collection Services, and the Office of Scholarly Communication
}

\author{
Michael Arthur \\ University of Central Florida, maarthur@ua.edu \\ Barbara G. Tierney \\ University of Central Florida
}

Follow this and additional works at: https://docs.lib.purdue.edu/charleston

Part of the Library and Information Science Commons

An indexed, print copy of the Proceedings is also available for purchase at:

http://www.thepress.purdue.edu/series/charleston.

You may also be interested in the new series, Charleston Insights in Library, Archival, and Information Sciences. Find out more at: http://www.thepress.purdue.edu/series/charleston-insights-library-archivaland-information-sciences.

Michael Arthur and Barbara G. Tierney, "Subject Librarian Initiative at the University of Central Florida Libraries: Collaboration Amongst Research and Information Services, Acquisitions and Collection Services, and the Office of Scholarly Communication" (2013). Proceedings of the Charleston Library Conference.

http://dx.doi.org/10.5703/1288284315311

This document has been made available through Purdue e-Pubs, a service of the Purdue University Libraries. Please contact epubs@purdue.edu for additional information. 


\title{
Subject Librarian Initiative at the University of Central Florida Libraries: Collaboration Amongst Research and Information Services, Acquisitions and Collection Services, and the Office of Scholarly Communication
}

\author{
Barbara G. Tierney, Head of Research and Information Services, University of Central Florida Libraries \\ Michael Arthur, Head of Acquisitions and Collection Services, University of Central Florida Libraries
}

\begin{abstract}
At the University of Central Florida Libraries, the Research and Information Services Department, the Acquisitions and Collection Services Department, and the Office of Scholarly Communication are collaborating to create and support a new Subject Librarian Service Model that focuses on proactive outreach to faculty and students. Since January 2013, these three units have worked closely together to emphasize the importance of Subject Librarians becoming more fully integrated into the university infrastructure through increased subject liaison roles. This collaboration has involved realigning, refining, and emphasizing the importance of the Subject Librarians' academic department and program assignments and training the librarians to perform informed outreach to advance collection development; scholarly communication; and faculty/student teaching, learning, and research.
\end{abstract}

\section{Changing Librarian's Role From Reactive To Proactive}

The new Subject Librarian initiative has sought to change the librarian's role from reactive to proactive. Instead of scheduling Reference Librarians to spend a significant portion of their day tied to a service desk or back office waiting for constituencies to come to them, we instead have spearheaded a new Subject Librarian Service Model that emphasizes the importance of proactive Subject Librarian outreach to the University of Central Florida (UCF) constituencies in support of collection development; scholarly communication; and faculty/student teaching, learning, and research.

The new UCF Subject Librarian Service Model is the product of the Research and Information Services Department, the Acquisitions and Collection Services Department, and the Office of Scholarly Communication working collaboratively to realign the librarians' subject assignments so as to more closely link each librarian with a particular UCF college (trying to keep all or most academic department and program assignments within the same UCF college) in order to maximize positive impacts on collection development; scholarly communication; and faculty/student teaching, learning, and research.

\section{Subject Librarians Profiling Their Academic Departments and Faculty and Performing Curriculum Mapping}

Activities supported by the three library departments to ensure the success of the newly minted Subject Librarians include:

- Academic department profiling by the Subject Librarians so that the Subject Librarians thoroughly understand the mission, goals, activities and new directions of their assigned academic departments and programs as well as the department's criteria for promotion, review, and tenure.

- Academic faculty profiling by the Subject Librarians so that the Subject Librarians are thoroughly acquainted with their assigned faculty members' research, grants, publications, and teaching assignments.

- Curriculum mapping by the Subject Librarians so that the Subject Librarians are thoroughly acquainted with the tiered curriculum of their assigned departments and programs in order to achieve more refined, on-target curriculum integrated 
library research instruction, and collection development.

\section{Enhancing the Visibility and Accessibility of Subject Librarians}

The new Subject Librarian Service Model emphasizes enhanced visibility and accessibility of Subject Librarians via the creation of a high profile Subject Librarian web site (http://library.ucf.edu/ SubjectLibrarians/) that publicizes the new Subject Librarian Service Model to academic departments, academic faculty, and students. The model is designed to visually connect Subject Librarians to their assigned constituencies and corresponding collection development assignments.

In addition to a new Subject Librarian web page, individual portraits of the Subject Librarians (along with their personal messages to the university community) are featured within the library's digital signage system. Also, a new photoenhanced Research and Information Services web site (http://library.ucf.edu/Reference/) adds to the visibility and prominence of the new Subject Librarian Service Model. This new web presence is linked directly to the existing web page for the Acquisitions and Collection Services Department so that librarians, faculty, and patrons have easy access to collection policies and information about recent key purchases that support the educational and research mission of the university. In order to fully appreciate the overall benefits of the new model it is important to have a general sense of what existed prior to 2013.

\section{Looking Back and Looking Ahead: The View from Collection Development}

UCF Collection Development was based on a Librarian-faculty Liaison Model with librarians from various departments across the library assigned to academic departments and special areas. While this part has not changed, there are now several key improvements. Prior to 2013, there were various levels of success depending on many factors, including the librarian-faculty relationship, response from departments, and time available to the librarian. The problems often came down to not enough time spent on collection development and less than effective interaction between the librarian and the assigned department. Another major problem developed over time as librarians were asked to accept new subject areas, often due to turnover, that were not related and were often not in the same college. Finally, there was not always strong support from the Head of Reference to address these issues and to raise collection development as a legitimate core responsibility.

The new collaboration between the previously stated functional areas has resulted in steps taken to address the negative points, and it has given a new sense of excitement about the possibilities that exist for increased involvement with faculty and academic departments. The use of adjunct librarians at the Research and Information Services Desk has freed the librarians to be more creative with outreach to the departments. The newly redesigned model has the strong support of the Head of Research and Information Services, who is working diligently to redirect the efforts of the librarians. This support sends a clear signal of the importance of being actively involved with collection development.

\section{The Importance of Positive Collaboration in Reaching Consensus}

In order to successfully implement these changes, all three departments had to work together. The Head of Collection Development and the Head of Research and Information Services focused on four specific areas including: realignment of subject areas, mutual public support for the new model, scholarly communication initiatives, and collection development training for librarians accepting new roles.

There was a mutual understanding that librarians should be assigned departments based on the commonality of subject matter, in order to realign the departments. This would allow for one librarian to be assigned to multiple departments (in some cases an entire college) thus contributing to continuity and better representation. In the past, librarians were working with departments from various colleges and were spread across disciplines that shared little in common. 
In order to build excitement for the changes, all three department heads were careful to publicly support the new model and to stress the importance of changing roles. It was essential that there be a give and take amongst the librarians regarding subject areas, and the department heads emphasized that, in the long run, faculty and students would be better able to identify the librarian assigned to their area and the message from the library would be more cohesive. In addition, with each librarian focused on related disciplines, more time could be spent focusing on those areas that would, in many cases, share resources and have similar goals for teaching and research.

The Head of Collection Development increased support for scholarly communication initiatives and began to send the message that many aspects of this emerging area are directly related to collection development. Librarians and selected staff members from technical services were encouraged to participate with the Scholarly Communication Advisory Group and began to acquire training that permitted them to serve at the Reference and Information Services Desk. The Collection Development Department collaborated with Reference and Information Services staff to link the new Subject Librarian web pages with those from the collection development web site and to blend the two sites for a better user experience. While librarians from Acquisitions and Collection Services had served at the Reference and Information Services Desk for several years, the new emphasis was on offering this opportunity to key support staff with the aptitude and interest for participating.

Subject Librarians, particularly those with new disciplines, were provided opportunities to meet with the Head of Collection Development to discuss their new roles and the increased expectations that were part of the move to the Subject Librarian Service Model.

\section{Subject Librarian Mobility and Outreach}

There is a new emphasis on Subject Librarians becoming mobile, getting out of the library building, spending quality time visiting their assigned academic departments, participating in departmental group meetings, and meeting oneon-one with faculty in their offices.

In addition to physically getting out of the library, the Subject Librarians also are proactively reaching out to their assigned academic departments and faculty through Subject Librarian-authored e-newsletters. What messages are the Subject Librarians taking to their academic departments and faculty? Frequently they are messages about collection development opportunities for the department.

Often, the librarians are alerting faculty to the amount of funds available for new monographs or updating them on major new purchases. Taking the time to advise faculty on channels of communication and giving them assurance that their voice is being heard will lead to better interaction and positive results. Here is an example of information provided to UCF faculty as excerpted from the Fall 2013 newsletter by Dr. Linda Colding (Subject Librarian to Public Affairs and Political Science):

The library will have $\$ 3,000$ to purchase materials this year. Please work with your library liaison to submit requests. This money is strictly for books and DVDs. One question I will have for you is whether you would like to purchase the item electronically. Unfortunately, we are not permitted to purchase journals with this money because those orders need to be renewed each year, and we don't know what our budget will be in the future. Also, sorry but no textbooks!

\section{Important Relationship Between Subject Librarians and Collection Development}

The important interaction between a dedicated librarian and an appointed faculty representative

remains at the heart of the new Subject Librarian Service Model. The development of positive relationships with the academic departments is the foundation for all other initiatives. Subject librarians still manage selection of monographs, DVDs, and other nonrecurring purchases and work collaboratively with the Head of Collection 
Development to address changes to ongoing titles, including periodicals and databases. Two key holdovers from the old model include department appointment (selected by Department Chair) of a faculty representative to the library and appointment of a librarian to interact directly with the department. The Head of Collection Development works directly with other department heads to select librarians and to assign each with specific collection development areas.

\section{How the New Model Differs from the Old}

The new look for UCF Collection Development started with the realignment of departments and assignments as well as the hiring of adjunct librarians to free up the subject librarians for expanded roles in outreach and collection development. Scholarly Communication is being emphasized across many departments at UCF, and, where possible, the new model serves to raise expectations for how librarians will themselves learn about scholarly communication initiatives and, in turn, become leaders in one or more areas. Scholarly communication and collection development share common goals of providing more access to scholarly works; reducing costs; and giving users more options for storing, retrieving, and sharing content.

The Subject Librarians also use their enewsletters to send out messages about scholarly communication services to their assigned academic departments and faculty. The UCF Libraries' Scholarly Communication Advisory Group encourages the Subject Librarians to participate in scholarly communication initiatives and provides support (both in person and via the Scholarly Communication web site) to the Subject Librarians as they reach out to their academic departments and faculty to explain and interpret scholarly communication and open access issues.

This year, the Scholarly Communication Advisory Group created a scholarly communication model entitled "Research Lifecycle at the University of Central Florida" which identified eight library roles within the research lifecycle. The Scholarly Communication Advisory Group then provided focused training for the Subject Librarians that concentrated on the eight identified intersections of library services within the UCF Research Lifecycle that included citation metrics, literature reviews, citation management tools, data management plans, data set metadata, discovery support, open access hosting, and metadata services.

The Subject Librarian goal is to provide practical assistance in helping academic faculty through the scholarly communication maze addressing topics such as copyright, open access, and author's rights. Subject Librarians communicate frequently with their assigned academic faculty about scholarly communication and open access issues. This year Subject Librarians have worked with their assigned academic departments to identify individual academic faculty members who are willing to serve as "UCF Open Access Champions" on the UCF Libraries' web site and in library programs and displays.

\section{Subject Librarian Training}

Research and Information Services, Acquisitions and Collection Services, and the Office of Scholarly Communication are all working to provide highly focused training for the Subject Librarians to support them in their new roles. The Research and Information Services Department has provided an all-day reference services retreat with training programs on academic department profiling, academic faculty profiling, curriculum mapping, goal-setting, assessment, and academic faculty expectations for Subject Librarians. The department also has created an online "Subject Librarian Toolkit" research guide to support the Subject Librarians in performing their new assignments.

The Scholarly Communication Advisory Group has provided a series of eight scholarly communication workshops (as well as providing access to a scholarly communication webinar series) that covers topics such as citation metrics, citation management tools, literature reviews, data management plans, data set metadata, discovery support, open access hosting, and metadata services. 
The Acquisitions and Collection Services Department has provided one-on-one assistance in fine tuning the Yankee Book Peddler (YBP) subject approval profiles for each Subject Librarian, and the Electronic Resource Librarian has provided training to enable each Subject Librarian to manage his/her own subject eresource web pages. All three departments have worked to create a "Subject Librarian Guidelines" white paper that supports and interprets the Subject Librarian Service Model.

\section{Specific Ways in Which Librarians Are Supported By Acquisitions and Collection Services}

The Head of Collection Development has been involved in many ways with support, training, and new initiatives as part of the new model. One-onone training is offered for Subject Librarians to clarify new roles and make the transition easier. The Electronic Resources Librarian has provided training so that each Subject Librarian can manage his/her own subject e-resource web pages. With the realignment of the librarians and academic departments in place, the Head of Collection Development managed a complete review of the YBP approval plan profile and got buy in for changes across disciplines. Support was given for joining new initiatives, including $\mathrm{SCOAP}^{3}$ and the Library Publishing Cooperative. Publishing vouchers are becoming a new trend (RSC Gold for Gold), and with this initiative the Head of Collection Development is coordinating with Research and Information Services and the Office of Scholarly Communication to effectively manage the vouchers. Finally, these three departments have worked together to create a "Subject Librarian Guidelines" white paper that supports and interprets the Subject Librarian Service Model.

\section{Measuring the Success of the New Subject Librarian Initiative}

How do we measure the success of the new Subject Librarian Service Model at the University of Central Florida Libraries? Success is measured by evaluating the overall impact of the new model. Do librarians feel more engaged with faculty? Are they given time to speak at academic faculty meetings and provided opportunities to distribute information about library services and new additions to the collection? Do the librarians feel that their time away from the Research and Information Services Desk is being used to develop a greater understanding of the research and educational mission of the academic departments they represent? Will this new knowledge advance scholarly communication initiatives and promote strong library collections through enhanced collection development decision making and more effective use of a limited materials budget?

The three functional areas that collaborated on this model share similar values and are working on a shared vision that will benefit each area. This new focus will direct our limited human resources toward common goals and result in greater outreach to the community we serve. The intent is that our outreach will foster a new sense of shared purpose with UCF academic units. Looking ahead to the future, the success of the new service model will be measured by:

- an increase in Subject Librarian outreach to academic departments and stronger faculty-librarian partnerships

- an increase in faculty participation in collection development and scholarly communication initiatives

- an increase in the number of student/faculty research consultations and curriculum-integrated library instruction sessions

- more informed collection development leading to even stronger collections and more effective use of UCF Libraries' limited materials budget

Implementation of the Subject Librarian Service Model has provided UCF Libraries with an opportunity to succeed in new ways and to develop stronger ties with UCF academic departments and programs. It also has led to increased collaboration amongst the three library units (Research and Information Services, Acquisitions and Collection Services, and the 
Office of Scholarly Communication) in support of the new Subject Librarian Service Model. This collaboration itself may be one of the most important achievements in the early days of this new model.

\section{References}

University of Central Florida Libraries. (2013a). Acquisitions and collection services. Retrieved from http://library.ucf.edu/CollectionMgmt/CollectionDevelopment/Librarians/RichardHarrison.php

University of Central Florida Libraries. (2013b) Scholarly communication. Retrieved from http://library.ucf.edu/ScholarlyCommunication/

University of Central Florida Libraries. (2013c) Subject librarian toolkit. Retrieved from http://guides.ucf.edu/aecontent. php?pid=466953

University of Central Florida Libraries. (2013d) Subject Librarians. Retrieved from http://library.ucf.edu/ SubjectLibrarians/

University of Central Florida Libraries Research Lifecycle Committee. (2013). The research lifecycle at UCF. Retrieved from http://library.ucf.edu/ScholarlyCommunication/ResearchLifecycleUCF.php 